\title{
How suitable are man-made water bodies as habitats for Odonata?
}

\author{
Marina Vilenica ${ }^{1}$, Ivana Pozojević ${ }^{2}$, Natalija Vučković ${ }^{2}$ and Zlatko Mihaljević ${ }^{2, *}$ \\ ${ }^{1}$ University of Zagreb, Faculty of Teacher Education, Trg Matice hrvatske 12, Petrinja, Croatia \\ ${ }^{2}$ University of Zagreb, Faculty of Science, Department of Biology, Rooseveltov trg 6, Zagreb, Croatia
}

Received: 2 December 2019 / Accepted: 27 February 2020

\begin{abstract}
Many studies have reported a negative impact of freshwater habitat modification on biota. Nevertheless, some man-made water bodies have proven to be valuable for biodiversity conservation as they can harbour many species. We investigated 36 man-made water bodies to determine their suitability as habitats for Odonata. Larvae were sampled in littoral, during the summer months of 2016 and 2017. At each sampling site, ten samples were collected using a benthos hand net. A total of 21 Odonata species was recorded. Odonata assemblages mainly consisted of common widespread species. Yet, at Vlačine Reservoir, located in the Dinaric Western Balkan ecoregion, we also recorded a rare and endangered Mediterranean species, Lindenia tetraphylla (Vander Linden, 1825). Aquatic and riparian vegetation, water level fluctuations and dissolved oxygen concentration had the highest influence on Odonata, showing that manmade water bodies with a well-developed riparian zone and aquatic vegetation, and with low daily and seasonal water level fluctuations, can provide suitable habitats for diverse Odonata species. Odonata are among the sensitive freshwater insects widely used as ecological indicators and umbrella species, therefore these results about their assemblages in heavily modified and man-made habitats could contribute to future conservation activities of freshwater biota and habitats.
\end{abstract}

Keywords: Dragonflies / environmental factors / aquatic and riparian vegetation / anthropogenic habitats / Lindenia tetraphylla

Résumé - Dans quelle mesure les lacs artificiels sont-ils adaptés à l'habitat d'Odonates ? De nombreuses études ont fait état d'un impact négatif des modifications des habitats d'eau douce sur leur biote. Néanmoins, certains lacs artificiels se sont révélés précieux pour la conservation de la biodiversité car ils peuvent abriter de nombreuses espèces. C'est pourquoi nous avons étudié 36 lacs artificiels afin de déterminer dans quelle mesure ils peuvent représenter des habitats appropriés pour les Odonates. Les larves ont été échantillonnées pendant les mois d'été 2016 et 2017. Sur chaque site d'échantillonnage, un total de dix échantillons a été collecté à l'aide d'un filet à main pour le benthos. Un total de 21 espèces d'Odonates a été enregistré. Les assemblages d'Odonates étaient principalement constitués d'espèces communes largement répandues. Cependant, sur le site de réservoir Vlačine, situé dans l'écorégion des Balkans occidentaux dinariques, nous avons également enregistré une des espèces méditerranéennes rares et menacées, Lindenia tetraphylla (Vander Linden, 1825). La végétation aquatique et rivulaire, la fluctuation du niveau d'eau et la concentration d'oxygène dissous ont eu la plus grande influence sur les Odonates, montrant que les lacs artificiels avec une végétation aquatique et une zone rivulaire bien développées, et avec de faibles fluctuations du niveau d'eau, peuvent fournir des habitats appropriés pour diverses espèces d'Odonates. Les Odonates font partie des insectes d'eau douce sensibles largement utilisés comme indicateurs écologiques et comme espèces parapluie. Nos résultats concernant leurs assemblages dans des habitats fortement modifiés et artificiels pourraient donc contribuer aux futures activités de conservation du biote et des habitats d'eau douce.

Mots clés : Libellules / facteurs environnementaux / végétation aquatique et rivulaire / habitats anthropiques / Lindenia tetraphylla

\footnotetext{
*Corresponding author: zlatko.mihaljevic@biol.pmf.hr
} 


\section{Introduction}

Odonata (dragonflies and damselflies) are among the most popular groups of aquatic invertebrates both among professional entomologists and the general public due to their large size, distinctive coloration and conspicuous behaviour (Barua et al., 2012; Boudot and Kalkman, 2015). Moreover, due to their diversity, amphibious life history, relatively short generation time, high trophic position, and sensitivity to small-scale anthropogenic changes in the environment (Samways and Steytler, 1996; Pinto et al., 2012), they are widely used as ecological indicators of habitat quality and the integrity of freshwater ecosystems (Smith et al., 2007; Simaika and Samways, 2011).

As a merolimnic insect order (having aquatic larvae and terrestrial adults), they represent an important link between freshwater and terrestrial habitats. Both larvae and adults are generalized predators that are rather opportunistic in prey selection (Corbet and Brooks, 2008; May, 2019). Habitat selection is one of the most important behavioural traits of Odonata, where each species favours a particular habitat type that offers the optimal conditions for reproduction and population maintenance (Corbet and Brooks, 2008). Larvae inhabit both lotic and lentic habitats, where their occurrence is strongly influenced by habitat morphology, and the presence and structure of aquatic and riparian vegetation. Adults use structural characteristics (aquatic and riparian vegetation and shading) as the main cues of habitat selection (Steytler and Samways, 1995; Corbet and Brooks, 2008). Dispersal is another important adult behavioural trait. Due to their high mobility and exploratory capacity, they can rapidly colonize newly-formed ponds and artificial water bodies (Askew, 2004).

Man-made water bodies have been constructed worldwide to serve various anthropocentric purposes. Historically, some were important sources of drinking water, while today they are mainly used as recreational areas in urban zones, for fish farming, irrigation in agriculture, or for flood control (Seaman and Sprague, 1991; Petrere, 1996). Many are constructed as reservoirs on running waters (Schwarz, 2012), with the main purpose of electricity generation (Petrere, 1996).

For decades, species richness has undergone an extraordinary global decline (Thomas et al., 2004), affecting both common and rare species (Inger et al., 2015). The main threats, especially for freshwater biota, are habitat loss, pollution and diverse anthropogenic habitat alterations (Thomas et al., 2004). As such, some habitats with conservation potential that were previously overlooked are now being considered as potentially important for biodiversity conservation (Dolný and Harabiš, 2012; Harabiš and Dolný, 2018). Many studies have examined the effects of anthropogenic modifications on freshwater biota (e.g. Zwick, 1992; Horsák et al., 2009; Vilenica et al., 2016a, 2019), showing negative consequences on biodiversity, changes in community composition and structure. On the other hand, some man-made water bodies that improve the development of the surrounding vegetation and represent important habitats for species of insects, fish and birds, could also be valuable for biodiversity conservation (Baxter, 1977; Irz et al., 2006; Vilenica et al., 2016b).
Biological assessments of freshwater habitats are crucial for their effective conservation and management (Hughes et al., 1986; Stoddard et al., 2008). This study was conducted as part of a comprehensive project, "Development of a classification system to assess the ecological potential of artificial and heavily modified surface water bodies", aimed at providing optimal data on the benthic ecology in man-made lentic habitats. As Croatia generally has few natural lakes, our main interest was to determine whether large artificial water bodies could represent adequate habitats for Odonata. Therefore, the main goals of this study were to (i) identify the composition and abundance of Odonata assemblages and (ii) determine the main environmental factors that influence Odonata in the studied man-made water bodies.

\section{Materials and methods}

\subsection{Study area}

We investigated 36 man-made water bodies, of which 21 are located in the Dinaric Western Balkan Ecoregion (ER 5) and 15 in the Pannonian Lowland Ecoregion (ER 11) in Croatia (Illies, 1978) (Fig. 1). The majority of these water bodies are reservoirs built on smaller or larger rivers used for water supply, irrigation or electricity generation, while several are natural though anthropogenically impacted water bodies (e.g. Prološko Blato, Sakadaš, Njivice) or artificial water bodies and gravel pits (e.g. Ponikve, Soderica Koprivnica, Rakitje, Novo Ćiče) used mainly for recreation. Some reservoirs used for electricity generation and irrigation (especially in ER 5, e.g. Lokve, Krušćica, Ričice, Peruća, Prančević) are characterized with high seasonal fluctuations of the water level, resulting in an absence of aquatic macrophytes.

\subsection{Sampling protocol}

We sampled benthic macroinvertebrates, including larvae of Odonata (damselflies and dragonflies) during the low water level period in the summer of 2016 and 2017 (from July to September). The littoral zones of all man-made water bodies were sampled once, at two or more locations (depending on reservoir size), applying a modified, proportional stratified sampling approach (Urbanič et al., 2012).

Each location sampled covered an area of $25 \mathrm{~m}$ lakeshore to a depth of 1 metre. At each location, we collected ten replicates using a benthic hand net $(25 \times 25 \mathrm{~cm}$ surface area, $500 \mu \mathrm{m}$ meshsize). Samples were taken in microhabitats covering at least $10 \%$ of the area, proportionate to their coverage at the sampling sites $(i$. $e$. lithal, fine sediment, xylal, CPOM, phytal). Substrate categories were defined according to the AQEM consortium (2002). To generate the "lithal" variable, we summed up the coverage percentages of megalithal, macrolithal, mesolithal and microlithal. To generate the "fine sediment" variable, we summed the coverage percentages of akal, psammopelal, pelal and psammal substrate (Tab. 1). Phytal included the coverage percentage of submerged macrophytes, floating aquatic plant species, and emergent vegetation.

Odonata larvae were identified to the lowest possible taxonomical level (very juvenile individuals were identified to the genus/family/suborder level) using Gerken and 


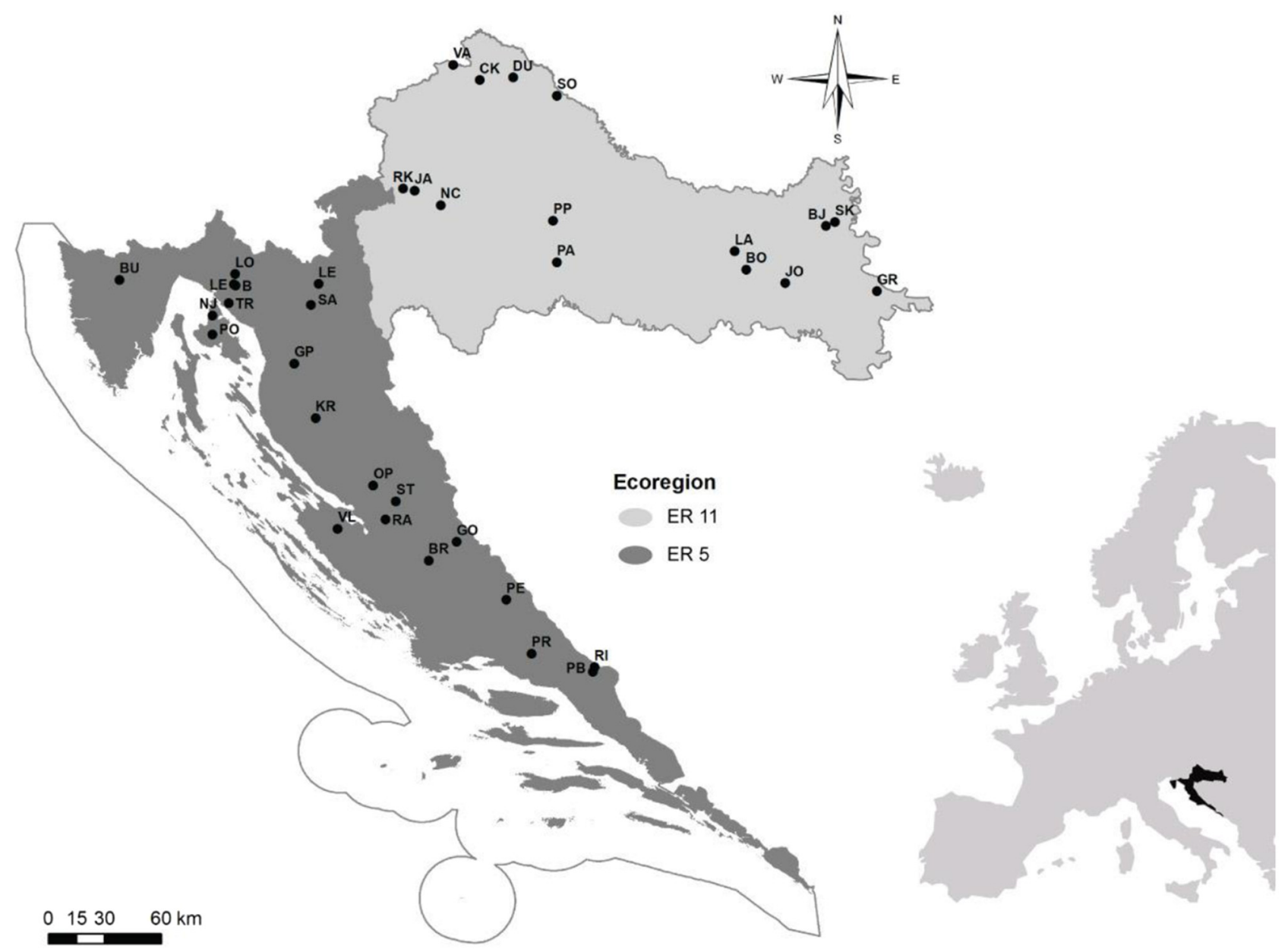

Fig. 1. Geographical position and locations of the 36 study sites. Study sites: ER 5: B - Bajer, BU - Butoniga, BR - Brljan, GO - Golubić, GPGusić polje, LP - Lepenica, LE - Lešće, LO - Lokve, NJ - Njivice, OP - Opsenica, PE - Peruća, PO - Ponikve, PR - Prančević, PB Prološko blato, RA - Razovac, RI - Ričice, SA - Sabljaci, ST - Štikada, TR - Tribalj, VL - Vlačine. ER 11: BJ - Biljsko jezero, SO Šoderica Koprivnica, RK - Rakitje, BO - Borovik, LA - Lapovac, JO - Jošava, NC - Novo Čiče, PA - Pakra, SK - Sakadaš, PP - Popovac, JA - Jarun, GR - Grabova, CK - Čakovec, DU - Dubrava, VA - Varaždin.

Sternberg (1999), combined with Askew (2004), and Brochard et al. (2012). All voucher specimens are deposited at the Department of Biology, Faculty of Science, University of Zagreb, Croatia.

\subsection{Environmental variables}

Simultaneously with the sampling of benthic macroinvertebrates in the littoral zone of each study site, we measured the following environmental parameters: water temperature, dissolved oxygen concentration (using the oximeter WTW Oxi 330/SET), conductivity (with the conductivity meter WTW LF 330) and $\mathrm{pH}$ (using the pH-meter WTW ph 330). The remaining environmental parameters are presented as the mean value of six composite samples from the euphotic zone collected over a six-month period (April-September, 2016 or 2017) (Tab. 1). Water chemistry analyses were carried out according to standard methods (APHA, 1992). Seasonal water level fluctuation values were grouped into five categories (Tab. 1) (Peterlin and Urbanič, 2013): (1) $0.00-0.25 \mathrm{~m}$, (2) $0.25-0.75 \mathrm{~m}$, (3) 0.75 $1.00 \mathrm{~m}$, (4) $1.00-5.00 \mathrm{~m},(5)>5.00 \mathrm{~m}$. On the basis of ARKOD (Croatian national land identification database) and field observations, the riparian zone cover around the investigated man-made water bodies was assessed and five classes were distinguished: (1) $<5 \%$, (2) $6-25 \%$, (3) $26-50 \%$, (4) $51-75 \%$, (5) $76-100 \%$. The riparian zone covers $10 \mathrm{~m}$ inland from the ordinary high water mark, and contains a variety of emergent vegetation, native woody and herbaceous plant species.

\subsection{Data analysis}

Non-metric multidimensional scaling analysis (NMDS) using the Bray-Curtis similarity index was used to determine similarities in the composition of Odonata assemblages among 
M. Vilenica et al.: Knowl. Manag. Aquat. Ecosyst. 2020, 421, 13

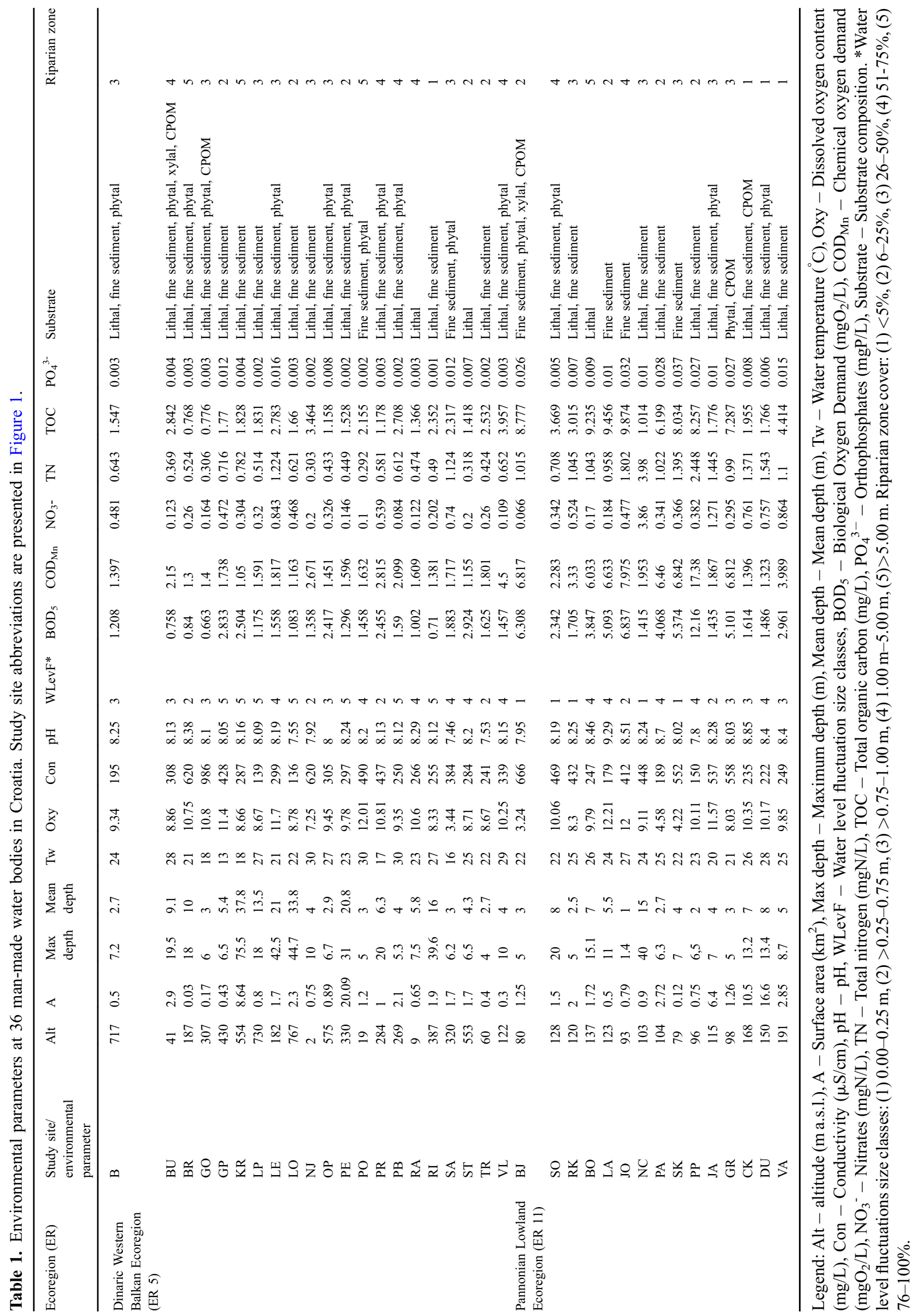


the study sites. Study sites without Odonata records were excluded from the analysis.

Redundancy analysis (RDA) was used to ordinate Odonata occurrence with respect to environmental variables. The analysis was performed using data for 28 taxa and 13 environmental variables (variables xylal, fine sediment, CPOM, COD were excluded due to colinearity). The Monte Carlo permutation test with 499 permutations was used to test the statistical significance of the relationship between all taxa and all variables.

The Bray-Curtis similarity index, HCA and NMDS analyses were conducted in Primer 6 (Clarke and Gorley, 2006). The RDA analysis was performed using CANOCO 5.00 (ter Braak and Smilauer, 2012). Species data were log transformed prior to analyses. All figures were processed with Adobe Illustrator CS6.

\section{Results}

\subsection{Odonata assemblages}

With 1808 collected and identified individuals, a total of 21 species was recorded (28 taxa; 7 taxa were juvenile individuals identified only to the genus/family/suborder level; Tab. 2). The number of individuals is presented per meter square (Tab. 2). The most widespread were Platycnemis pennipes (Pallas, 1771) and Orthetrum albistylum (Selys, 1848) recorded at nine study sites, while several species were recorded at only one study site (Erythromma viridulum (Charpentier, 1840), Sympecma fusca (Vander Linden, 1820), Aeshna mixta (Latreille, 1805), Hemianax ephippiger (Burmeister, 1839) and Lindenia tetrapyhlla (Vander Linden, 1825)).

No Odonata larvae were collected at the study sites Bajer, Krušćica, Prančević, Štikada, Lapovac and Čakovec, while the highest number of taxa was recorded at Ponikve and Vlačine (17 and 16, respectively; Fig. 2). Ponikve Reservoir also had the highest Odonata abundance $\left(243.8 / \mathrm{m}^{2}\right)$.

NMDS analysis showed very low similarity in Odonata assemblages among the study sites, approximately 5\%. For the most part, study sites did not group based on ecoregion (Fig. 3).

\subsection{Odonata and environmental variables}

The results of the ordination of Odonata taxa and environmental data of the RDA analysis are shown in an F1 $\times$ F2 ordination plot (Fig. 4). The distribution of Odonata fauna was highly related to axes 1 and 2, with eigenvalues of 0.16 and 0.06 , showing a species-environment correlation of $70.7 \%$. The Monte Carlo permutation test indicated that the species-environment ordination was significant (first axis: $F$-ratio $=12.71, P=0.002$; overall: trace $=0.31, P=0.002$ ), suggesting that species were significantly related to the tested set of environmental variables. Axis 1 was related to phytal substrate $(R=0.36)$ and riparian zone $(R=0.36)$, and axis 2 to dissolved oxygen concentration $(R=-0.36)$ and water level fluctuation $((R=-0.32)$, indicating that these were the most important parameters in explaining patterns of Odonata assemblages.

\section{Discussion}

This study recorded rather high Odonata species richness, with $32 \%$ of the overall Croatian Odonata fauna (Belančić et al., 2008; Boudot and Kalkman, 2015). On the other hand, species richness was lower in comparison with some natural wetland habitats (Vilenica et al., 2011; Kulijer, 2012; De Knijf et al., 2013). However, the sampling method has certain limitations, as it may under-collect representative larvae given the rather small area of habitat/microhabitat captured by the sampling net (Horning and Pollard, 1978; Martín and Maynou, 2016).

Moreover, sampling only in the summer is another limitation, e.g. by this time, spring species (species overwintering in the last larval stage and emerging next spring) have already emerged or were too rare or juvenile to be identified to the species level. Hence, supplementary surveying should include sampling of spring species, together with exuviae and adults (Samways et al., 2009; Raebel et al., 2010) to obtain more accurate species richness for each site, which is surely to be higher than recorded here (Vilenica et al., 2016b).

Corroborating previous studies on Odonata in disturbed habitats (e.g. Steytler and Samways, 1995), their assemblages in the present study mainly consisted of widespread, generalist species, indicating that man-made water bodies are of little importance for the distribution and protection of rare species. On the other hand, some studies have shown that anthropogenic habitats can provide suitable habitat for many populations of protected species (e.g. Dolný and Harabiš, 2012; Holtmann et al., 2018; Renner et al., 2016).

Since most of the study sites investigated in this study are reservoirs built on rivers, stream zonation preferences revealed that the majority of the recorded species were predominantly littoral (e.g. L. depressa, H. ephippiger, S. fusca, C. puella). Additionally, we recorded some lotic species that can also reproduce in well oxygenated lentic systems (such as O. forcipatus, G. vulgatissimus) and species that inhabit a wide range of freshwater habitats (such as P. pennipes and I. elegans) (Janecek et al., 1995; Schmedtje and Colling, 1996; Kalkman et al., 2018). Platycnemis pennipes, the most frequently recorded species, inhabits both slow flowing lotic and well-oxygenated lentic habitats with well-developed aquatic vegetation (Askew, 2004; Dijkstra and Lewington, 2006). As the majority of study sites are well oxygenated, this species was recorded both from well-vegetated sites, such as Vlačine and Šoderica, but also from poorly vegetated ones, such as Jošava and Novo Čiče. Orthetrum albistylum, another frequent species, predominantly inhabits lakes and ponds, but as females oviposit by dipping their abdomen into the water (Askew, 2004; Dijkstra and Lewington, 2006) and larvae of Orthetrum species lurk for their prey from the sediment (Corbet and Brooks, 2008), the presence of aquatic vegetation is not crucial, as reported by Vilenica et al. (2011). Therefore, it was mainly recorded in sites with very little to no aquatic vegetation.

Various environmental factors are linked to the complex habitat requirements of Odonata, such as water temperature, dissolved oxygen content, substrate composition, current velocity (e.g. McPeek, 2008; Corbet and Brooks, 2008; Vilenica, 2017), but also biotic factors such as aquatic and riparian vegetation structure, food resources, parasites and 


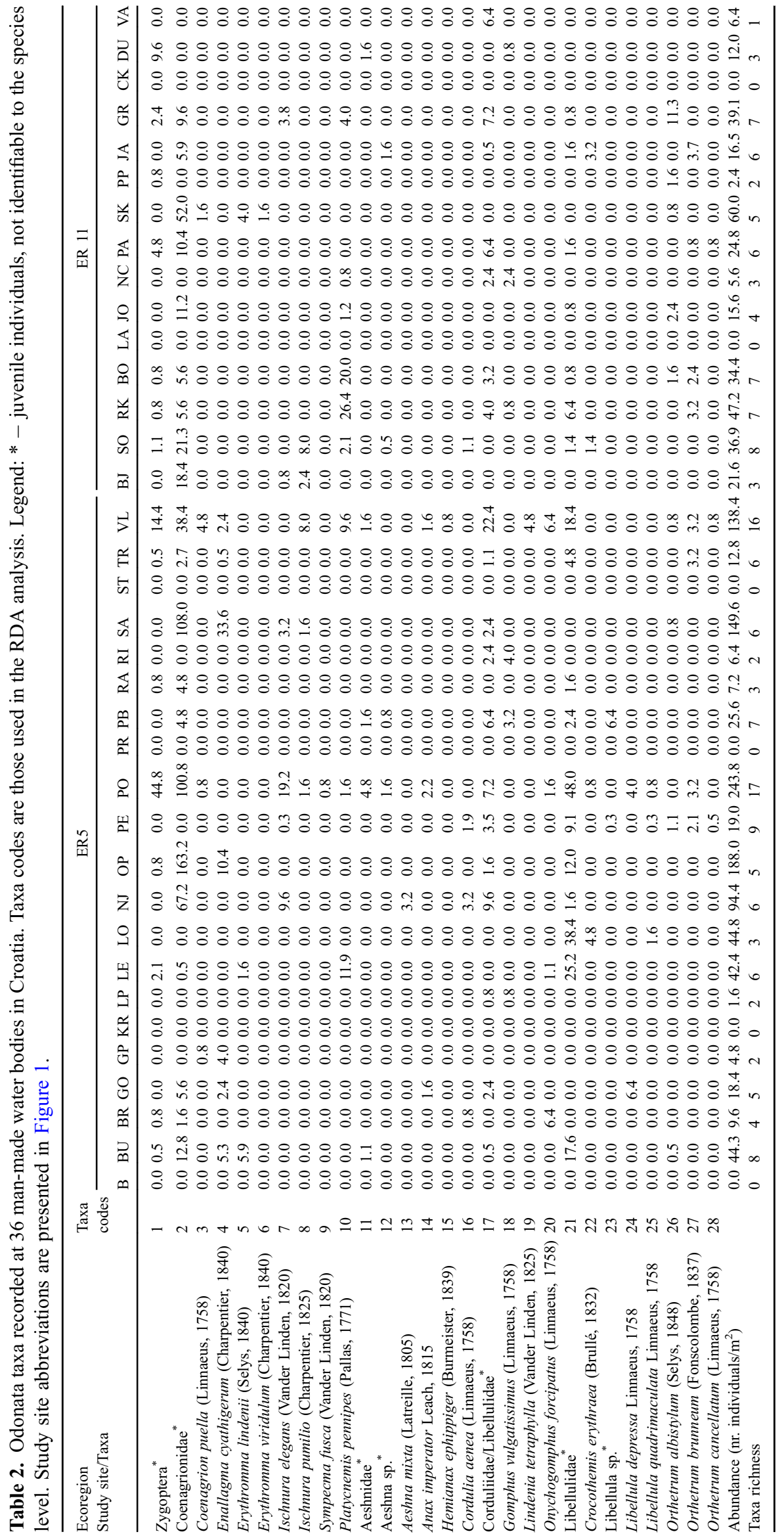



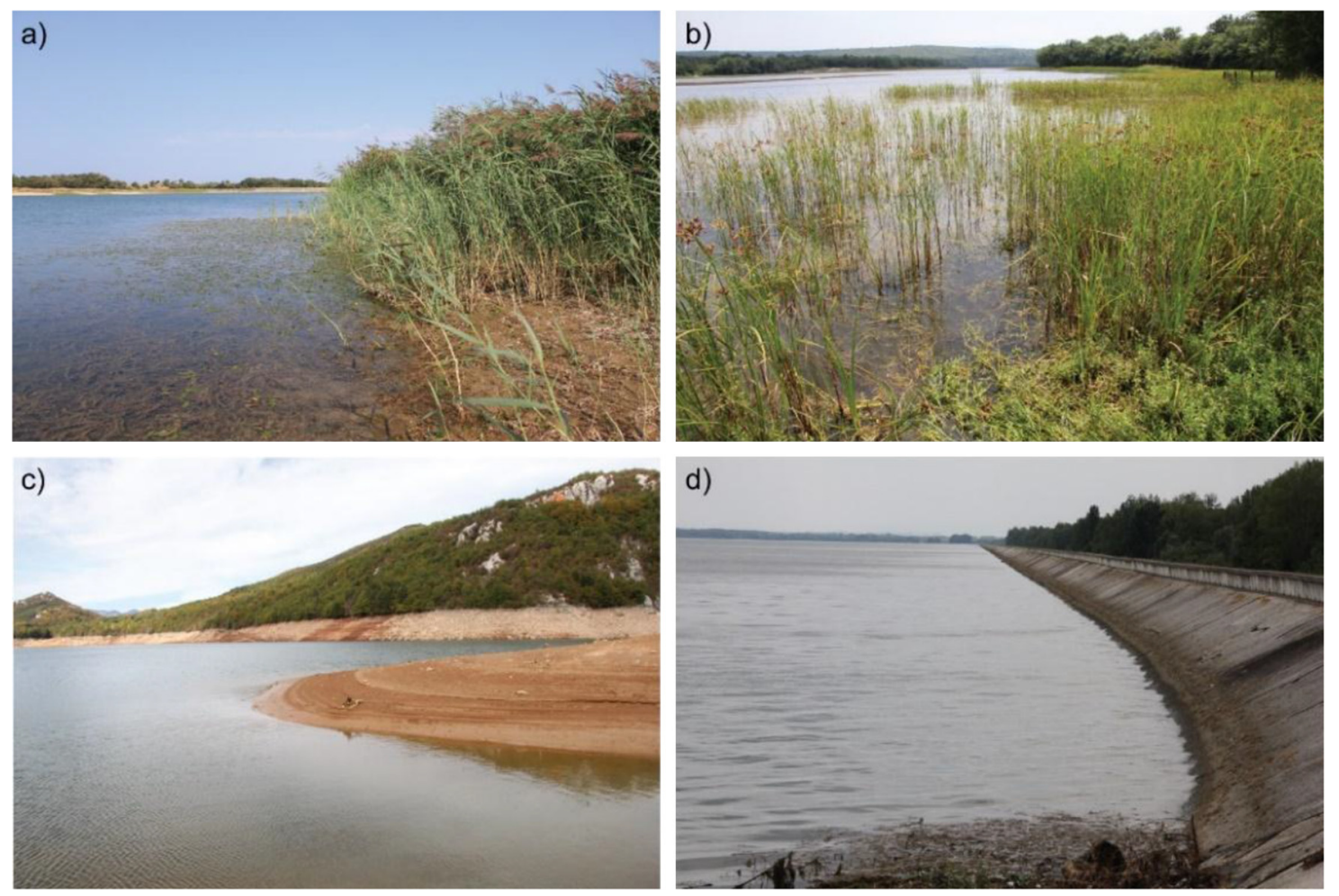

Fig. 2. Examples of the investigated man-made water bodies: a) Vlačine (ER5) and b) Ponikve (ER5) with highest Odonata taxa richness, and c) Krušćica (ER5) and d) Cakovec (ER11) without Odonata records.

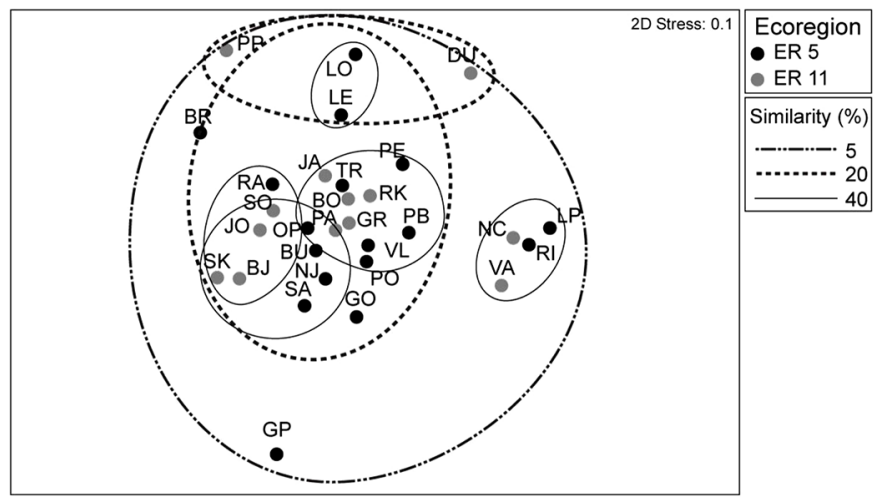

Fig. 3. Non-metric multidimensional scaling (NMDS) ordination of Odonata assemblages based on the Bray-Curtis similarity coefficient (group average linking) and their log-transformed abundances at 36 man-made water bodies in Croatia. Abbreviations of the study sites are presented in Figure 1.

predators (McPeek, 2008). Habitat heterogeneity was recognized as one of the most important variables determining the appearance of a particular dragonfly species in a habitat, i.e. the presence, quantity and composition of diverse shoreline, semiaquatic and aquatic vegetation (Lenz, 1991; Schindler et al., 2003). Emerged and riparian vegetation is a crucial feature in Odonata life as many larvae use vegetation to lurk for prey (Zygoptera, Anax, Sympetrum), or to hide from predators, while adults use it for oviposition and perching (Corbet and

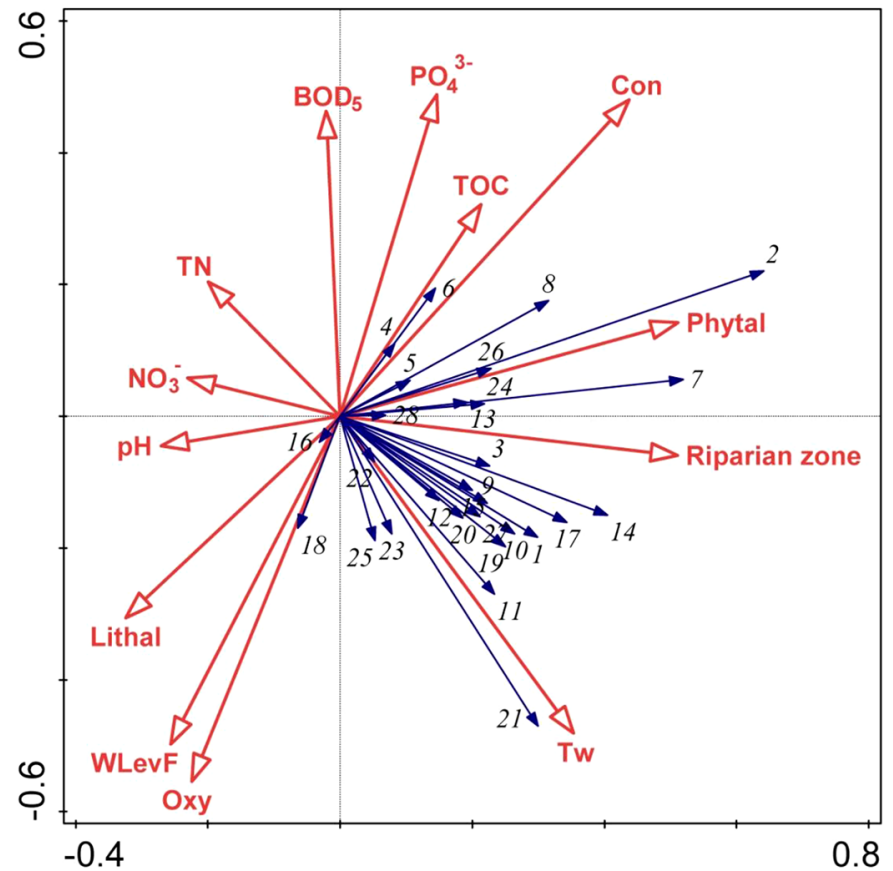

Fig. 4. $\mathrm{F} 1 \times \mathrm{F} 2$ plane of redundancy analysis for 28 Odonata taxa and 13 environmental variables. Legend: Values and abbreviations of environmental parameters (red arrows) are presented in Table 1 and taxa codes (blue arrow symbols) are presented in Table 2. 
Brooks, 2008). Many freshwater invertebrates used as ecological indicators are rather sensitive to water pollution, such as mayflies (Vilenica et al., 2019). Unlike them, Odonata are not generally able to reflect water pollution (e.g. Takamura et al., 1991), but are more sensitive to changes in the structure and integrity of macrophyte vegetation in their habitat (Schindler et al., 2003; Harabiš and Dolný, 2012). Therefore, it is not surprising that the RDA analysis determined phytal (i.e. the quantity of aquatic vegetation at habitat) and riparian zone cover to be the most important variables for Odonata assemblages in the studied man-made water bodies. Data on the composition of littoral aquatic vegetation of the studied man-made water bodies are available, but were not considered since most Odonata species generally show little response to particular plant species (terrestrial or aquatic) (e.g. Foote and Hornung, 2005), and their abundance is often positively correlated with the local abundance of vegetation (as reviewed in Remsburg, 2007). Macrophyte structure and abundance are negatively affected by an increase of water level fluctuations (van Geest et al., 2005). Study sites with low daily and seasonal water level fluctuations also had diverse and abundant aquatic vegetation, and therefore higher Odonata species richness and abundance. On the other hand, no Odonata specimens were collected from those with high water level fluctuations and without vegetation. Man-made water bodies with the highest daily and seasonal water level fluctuations and water losses are situated mostly in the Dinaric karst area, as they lie directly within carbonate rock (Bonacci and RojeBonacci, 2008). Furthermore, dense, submerged and floating macrophytes reduce the concentrations of dissolved oxygen in water (Rose and Crumpton, 1996), hence the negative RDA correlation with Odonata assemblages.

Among the significant results was the discovery of an eremic gomphid, Lindenia tetraphylla, a species listed in Annexes II and IV of the Habitats Directive, and listed as Vulnerable (VU) on the European Red List (Kalkman et al., 2010). Its distribution extends from Central Asia and Pakistan to parts of the Arabian Peninsula and the Western Mediterranean Basin (Boudot and Kalkman, 2015). In the Mediterranean, it preferably inhabits large lakes, with dense and diverse aquatic and riparian vegetation, where relatively few stable populations are found (e.g. Boudot et al., 2009; Boudot, 2014; Stille et al., 2014). Larvae, but also exuviae (Vilenica et al., 2016b), were recorded in the Vlačine Reservoir, where habitat conditions, i.e. vegetation structure and physico-chemical water properties, proved to be suitable for this species. This record is evidence of the species' reproduction at the northwestern border of its distribution (Vilenica et al., 2016b). Vlačine Reservoir was a suitable habitat for another interesting Mediterranean species, Selysiothemis nigra (Vander Linden, 1825), as reported by Vilenica et al. (2016b).

In conclusion, this study provides new insight into the relationship of Odonata and the anthropogenic environment, and the results can be useful for species and habitat conservation. Man-made water bodies could be suitable habitats for diverse Odonata species, but only if they are characterized by adequate environmental conditions, i.e. required water chemistry and well-developed riparian and aquatic vegetation. Less suitable ones with a poorer structure of macrophyte vegetation could serve as habitats for eurytopic species with low ecological requirements that are still able to reproduce there. Moreover, although these man-made water bodies mostly harbour widespread and common species, in some cases, they also provide suitable habitat for some rare and endangered ones. The results of this study could contribute to the successful development of a monitoring system for manmade water bodies according to the requirements of the European Water Framework Directive.

Acknowledgements. Our colleagues from the University of Zagreb (Faculty of Science, Department of Biology, Division of Zoology) and Josip Juraj Strossmayer University of Osijek (Department of Biology) are thanked for their indispensable assistance during field studies, and for assistance in sorting the collected materials. Miran Katar and Maja Kerovec are thanked for their help with the artwork.

\section{Author contribution statement}

ZM designed and supervised the research; MV and IP identified the specimens, MV analyzed the data and wrote the paper; ZM, IP and NV collected the samples; NV sorted the samples. All authors edited the drafts and approved the final version of the manuscript.

\section{References}

APHA. 1992. Standard methods for the examination of water and wastewater, 18th ed. Washington, DC: American Public Health Association, $1409 \mathrm{p}$.

AQEM consortium. 2002. Manual for the application of the AQEM method - A comprehensive method to assess European streams using benthic macroinvertebrates, developed for the purpose of the Water Framework Directive, Version 1.0, February 2002, 198 p.

Askew RR. 2004. The dragonflies of Europe, 2nd ed. Essex: Harley Books, 308 p.

Barua M, Gurdak DJ, Ahmed RA, Tamuly J. 2012. Selecting flagships for invertebrate conservation. Biodivers Conserv 21: 1457-1476.

Baxter RM. 1977. Environmental effects of dams and impoundments. Annu Rev Ecol Evol Syst 8: 255-283.

Belančić A, Bogdanović T, Franković M, Ljuština M, Mihoković N, Vitas B. 2008. Crvena knjiga vretenaca Hrvatske, Ministarstvo kulture, Državni zavod za zaštitu prirode Republike Hrvatske, Zagreb, 132 p. (In Croatian). (Red book of Croatian Odonata, Ministry of culture, State institute for nature protection, Croatia, Zagreb.

Bonacci O, Roje-Bonacci T. 2008. Water losses from the Ričice reservoir in the Dinarickarst. Eng Geol 99: 121-127.

Boudot J-P, Kalkman VJ, Azpilicueta Amorín M, Bogdanović T, Cordero Rivera A, Degabriele G, Dommanget JL, Ferreira S, Garrigós B, Jović M, Kotarac M, Lopau W, Marinov M, Mihoković N, Riservato E, Samraoui B, Schneider W. 2009. Atlas of the Odonata of the Mediterranean and North Africa. Libellula Supplement 9, $256 \mathrm{p}$.

Boudot J-P. 2014. A brief observation of egg laying in Lindenia tetraphylla (Odonata: Gomphidae) on Kríti (Crete), Greece. Not odonatol 8: 94-96.

Boudot J-P, Kalkman VJ. 2015. Atlas of the European dragonflies and damselflies. the Netherlands: KNNV publishers, $381 \mathrm{p}$.

Brochard C, Groendijk D, van der Ploeg E, Termaat T. 2012. Fotogids Larvenhuidjes van Libellen. Zeist: KNNV uitgeverij, 320 p.

Clarke KR, Gorley RN, 2006. Primer V6: User manual/tutorial. Plymouth: Primer-E Ltd., 192 p. 
Corbet P, Brooks S. 2008. Dragonflies, Collins New Naturalist Library No 106. London: HarperCollins, 480 p.

De Knijf G, Vanappelghem C, Demolder H. 2013. Odonata from Montenegro, with notes on taxonomy, regional diversity and conservation. Odonatologica 42: 1-29.

Dijkstra K-DB, Lewington R. 2006. Field guide to the dragonflies of Britain and Europe. Gillingham: British Wildlife Publishing, $320 \mathrm{p}$.

Dolný A, Harabiš F. 2012. Underground mining can contribute to freshwater biodiversity conservation: allogenic succession forms suitable habitats for dragonflies. Biol Conserv 145: $109-117$.

Foote AL, Hornung CLR. 2005. Odonates as biological indicators of grazing effects on Canadian prairie wetlands. Ecol Entomol 30: 273-283.

Gerken B, Sternberg K. 1999. Die Exuvien Europaïscher Libellen The exuviae of European dragonflies (Insecta, Odonata). Hökster, Jena: Arnika \& Eisvogel, 354 p.

Harabiš F, Dolný A. 2012. Human altered ecosystems: suitable habitats as well as ecological traps for dragonflies (Odonata): the matter of scale. J Insect Conserv 16: 121-130.

Harabiš F, Dolný A. 2018. Military training areas as refuges for threatened dragonfly species: Effect of spatial isolation and military activity. Biol Conserv 217: 28-35.

Holtmann L, Juchem M, Brüggeshemke J, Möhlmeyer A, Fartmann T. 2018. Stormwater ponds promote dragonfly (Odonata) species richness and density in urban areas. Ecol Eng 118: $1-11$.

Horning CE, Pollard JE. 1978. Macroinvertebrate sampling techniques for streams in semi-arid regions: Comparison of the Surber method and unit-effort traveling Kick method, Report number EPA 600-4-78-040. Washington: US EPA, 37 p.

Horsák M, Bojková J, Zahrádková S, Omesová M, Helesic J. 2009. Impact of reservoirs and channelization of lowland river macroinvertebrates: a case study from Central Europe. Limnologica 39: $140-151$.

Hughes RM, Larsen DP, Omemik JM, 1986. Regional reference sites: a method for assessing stream pollution. Environ Manag 10: 629-635.

Illies J. 1978. Limnofauna Europaea, 2nd ed. Stuttgart: Gustav Fischer Verlag, $532 \mathrm{p}$.

Inger R, Gregory R, Duffy JP, Stott I, Voříšek P, Gaston KJ. 2015. Common European birds are declining rapidly while less abundant species' numbers are rising. Ecol Lett 18: 28-36.

Irz P, Odion M, Argillier C, Pont D. 2006. Comparison between the fish communities of lakes, reservoirs and rivers: Can natural systems help define the ecological potential of reservoirs? Aquat Sci 68: 109-116.

Janecek BFU, Moog O, Waringer J. 1995. Odonata. In: Moog O, ed. Fauna aquatica Austriaca: A comprehensive species inventory of Austrian aquatic organisms with ecological notes. Wien: Federal Ministry of Agriculture and Forestry, $14 \mathrm{p}$.

Kalkman VJ, Boudot J-P., Bernard R, et al. 2010. European red list of dragonflies. Luxembourg: Publications Office of the European Union, $38 \mathrm{p}$.

Kalkman V, Boudot J, Bernard R, De Knijf G, Suhling F, Termaat T. 2018. Diversity and conservation of European dragonflies and damselflies (Odonata). Hydrobiologia 811: 269-282.

Kulijer D. 2012. Odonata species and habitats at Livanjsko polje karst wetland area. Int Dragonfly Fund Rep 48: 1-38.

Lenz N. 1991. The importance of abiotic and biotic factors for the structure of odonate communities of ponds (Insecta: Odonata). Faun Ökol Mitt 6: 175-189.
Martín R, Maynou X. 2016. Dragonflies (Insecta: Odonata) as indicators of habitat quality in Mediterranean streams and rivers in the province of Barcelona (Catalonia, Iberian Peninsula). Int $J$ Odonatol 19: 107-124.

May ML. 2019. Odonata: who they are and what they have done for us lately: classification and ecosystem services of dragonflies. Insects 10: 62 .

McPeek MA. 2008. Ecological factors limiting the distributions and abundances of Odonata. In: Córdoba-Aguilar A, ed. Dragonflies and damselflies: model organisms for ecological and evolutionary research. Cambridge, Massachusetts, USA: Harvard University Press, pp. 51-62.

Peterlin M, Urbanič G. 2013. A Lakeshore Modification Index and its association with benthic invertebrates in alpine lakes. Ecohydrology 6: 297-311.

Petrere M. 1996. Fisheries in large tropical reservoirs in South America. Lakes Reserv Res Manag 2: 111-133.

Pinto NS, Juen L, Cabette HSR, De Marco P Jr. 2012. Fluctuating asymmetry and wing size of Argia tinctipennis Selys (Zygoptera: Coenagrionidae) in relation to riparian forest preservation status. Neotrop Entomol 41: 178-185.

Raebel EM, Merckx T, Riordan P, Macdonald DW, Thompson DJ. 2010. The dragonfly delusion: why it is essential to sample exuviae to avoid biased surveys. $J$ Insect Conserv 14: 523-534.

Remsburg AJ. 2007. Aquatic and terrestrial vegetation influence lacustrine dragonfly (order Odonata) assemblages at multiple life stages, $\mathrm{PhD}$ Thesis, University of Wisconsin- Madison, Wisconsin, $127 \mathrm{p}$.

Renner S, Périco E, Sahlén G. 2016. Man-made lakes form speciesrich dragonfly communities in the Brazilian Atlantic Forest (Odonata). Odonatologica 45:135-154.

Rose C, Crumpton WG. 1996. Effects of emergent macrophytes on dissolved oxygen dynamics in a prairie pothole wetland. Wetlands 16: 495-502.

Samways MJ, McGeoch MA, New TR. 2009. Insect conservation: handbook of approaches and methods. Oxford: Oxford University Press, $432 \mathrm{p}$.

Samways MJ, Steytler NS. 1996. Dragonfly (Odonata) distribution patterns in urban and forest landscapes, and recommendations for riparian management. Biol Conserv 78: 279-288.

Schindler M, Fesl C, Chovanec A. 2003. Dragonfly associations (Insecta: Odonata) in relation to habitat variables: a multivariate approach. Hydrobiologia 497: 169-180.

Schmedtje U, Colling M. 1996. Ökologische Typisierung der aquatischen Makrofauna, Informationsberichte des Bayerischen Landesamtes für Wasserwirtschaft 4/96, 543 p.

Schwarz U. 2012. Balkan rivers - The blue heart of Europe, Hydromorphological status and dam projects, Report for EcoWatch-Austria and EuroNatur, Vienna, Austria, 151 p.

Seaman W, Sprague LM. 1991. Artificial habitats for marine and freshwater fisheries San Diego, CA: Academic Press, 267 p.

Simaika JP, Samways MJ. 2011. Comparative assessment of indices of freshwater habitat conditions using different invertebrate taxon sets. Ecol Indic 11: 370-378.

Smith J, Samways MJ, Taylor S. 2007. Assessing riparian quality using two complementary sets of bioindicators. Biodivers Conserv 16: $2695-2713$

Stille M, Stille B, Schröter A. 2014. Lindenia tetraphylla - new for the island of Kérkira (Corfu), Greece (Odonata: Gomphidae). Not odonatol 8: 86-90.

Steytler NS, Samways MJ. 1995. Biotope selection by adult male dragonflies (Odonata)at an artificial lake created for insect conservation in South Africa. Biol Conserv 72: 381-386. 
Stoddard JL, Herlihy AT, Peck DV, Hughes RM, Whittier TR, Tarquinio E. 2008. A process for creating multimetric indices for large-scale aquatic surveys. $J N$ Am Benthol Soc 27: 878-891.

Takamura K, Hatakeyama S, Shiraishi H. 1991. Odonata larvae as an indicator of pesticide contamination. Appl Entomol Zool 26: 321-326.

ter Braak CJF, Smilauer P. 2012. Canoco reference manual and user's guide: Software for ordination, Version 5.0. Ithaca, NY: Microcomputer Power, $496 \mathrm{p}$.

Thomas JA, Telfer MG, Roy DB, et al. 2004. Comparative losses of British butterflies, birds, and plants and the global extinction crisis. Science 303: 1879-1881.

Urbanič G, Petkovska V, Pavlin M. 2012. The relationship between littoral benthic invertebrates and lakeshore modification pressure in two alpine lakes. Fundam Appl Limnol 180: 157-173.

van Geest GJ, Wolters H, Roozen FCJM, et al. 2005. Water-level fluctuations affect macrophyte richness in floodplain lakes. Hydrobiologia 539: 239-248.
Vilenica M, Mičetić Stanković V, Franković M. 2011. Dragonfly fauna (Insecta, Odonata) in the Turopolje region (Croatia). Nat Croat 20: 141-158.

Vilenica M, Previšić A, Ivković M, et al. 2016a. Mayfly (Insecta: Ephemeroptera) assemblages of a regulated perennial Mediterranean river system in the Western Balkans. Biologia 71: 1038-1048.

Vilenica M, Alegro A, Koletić N, Mihaljević Z. 2016b. New evidence of Lindenia tetraphylla (Vander Linden, 1825) (Odonata, Gomphidae) reproduction at the north-western border of its distribution. Nat Croat 25: 287-294.

Vilenica M. 2017. Ecological traits of dragonfly (Odonata) assemblages along an oligotrophic Dinaric karst hydrosystem. Ann Limnol - Int J Lim 53: 377-389.

Vilenica M, Vučković N, Mihaljević Z. 2019. Littoral mayfly assemblages in South-East European man-made lakes. J Limnol 78: 47-59.

Zwick P. 1992. Stream habitat fragmentation-a threat to biodiversity. Biodivers Conserv 1: 80-97.

Cite this article as: Vilenica M, Pozojević I, Vučković N, Mihaljević Z. 2020. How suitable are man-made water bodies as habitats for Odonata? Knowl. Manag. Aquat. Ecosyst., 421, 13. 